\title{
Holocaust literature and historiography in Anne Michaels' Fugitive Pieces
}

Journal of European Studies 43(I) 14-26

(C) The Author(s) 2013

Reprints and permission: sagepub. co.uk/journalsPermissions.nav DOI: I0.I I77/0047244 I I 2470084 jes.sagepub.com

\section{Victoria Nesfield}

York St John University

\section{Philip Smith}

Loughborough University

\begin{abstract}
This paper examines Anne Michaels' Fugitive Pieces (2007) in the context of Holocaust literature and historiography. It begins with an introduction to the genre of Holocaust literature and the problematic nature of 'survivor' testimony. Michaels' work is then contextualized within this body of literature. The essay goes on to examine the means through which Michaels approaches the act of writing history, specifically the recording of history through alternative means to the hegemonic historiography utilized by the Nazis.
\end{abstract}

\section{Keywords}

Fugitive Pieces, historiography, Holocaust fiction, literature, Anne Michaels, Shoah, testimony

\section{The paradox of the true witness}

There is an immediate paradox to the very notion of Holocaust literature, either fictional or non-fictional, as a genre. ${ }^{1}$ In October 1943, Himmler said of the Holocaust 'This is a page of glory in our history which has never to be written and is never to be written' (Gilbert, 1987: 614). His statement, ostensibly concerning his perceived need to cover up what was to occur, reflects the inherently unspeakable nature of the events, not only in terms of the inexpressibility and silence of trauma, but of the gaps in Holocaust testimony - those absent voices that did not survive to describe what happened to them.

In response to the publication of French academic Robert Faurisson's assertions that he could find no witness from the Holocaust who could truly assert that they 'had seen

\section{Corresponding author:}

Victoria Nesfield, Faculty of Education and Theology, York St John University, Lord Mayor's Walk, York, YO3 I 7EX, UK

Email: v.nesfield@yorksj.ac.uk 
with their own eyes a gas chamber', philosopher Jean-François Lyotard wrote of the witnesses and of the ethics of testifying to the Shoah:

Most of them disappeared then, and the survivors rarely speak about it. When they do speak about it, their testimony bears only a minute part of this situation. How can you know that the situation itself existed? That it is not the fruit of your informant's imagination? (Lyotard, 1988: 3)

If the Shoah was to be a never-to-be-written page in Nazi history, and the Jews were to be entirely eliminated from history, then the survivors of the Shoah, according to Lyotard, were not the true witnesses, or they were only able to produce a limited view of the Shoah at best, and a false testimony at worst.

Lyotard's assertion that the survivors of the Shoah are not history's true witnesses is supported by Primo Levi, one of the first-published, and most highly esteemed voices of Shoah memory, who asserted in his first testimony that: 'the drowned have no story' (Levi, 1960: 96). As one of 'the saved', in his own vocabulary, Levi's public status as witness, and the ethics of testifying more broadly, concerned Levi. His imperative to tell his story conflicts with his discomfort at being represented as one of the victims.

At a distance of years one can definitely affirm that the history of the Lagers has been written almost exclusively by those who, like myself, never fathomed them to the bottom. Those who did so did not return, or their capacity for observation was paralysed by suffering and incomprehension. (Levi, 1988: 6)

Despite the concern expressed by Levi, a wave of testimonies (non-testimonies by Lyotard's assessment) proliferated in the 1950s and has continued for over half a century. The Shoah literature market is filled with the testimonies of those who did not sink to the bottom, those who were saved and have a story to tell. The trajectories of the testimonies are broad and representative of the disparity of the survivors. More tellingly, the variety of testimonies produced in the aftermath of the Shoah is indicative of the communities enveloped by the Nazi persecutions and the Final Solution juggernaut. There is not one Holocaust story to have witnessed. Rather, there are as many stories as there were individuals involved.

In the first few years following the defeat of Nazi Germany and the liberation of the camps the first testimonies emerged, telling the stories of the Jews of Europe, from the secular, assimilated Jews of Western Europe (Primo Levi's If This Is a Man) and the devout Hasidic Jews of the East, deported from small remote communities away from the war-fronts (Elie Wiesel's Night), to the wives and mothers whose testimonies are laden with the memories of their families being torn apart (Olga Lengyel's Five Chimneys). After years of resistance to the publication of Shoah testimonies in Europe and a reluctance to acknowledge the full horrors laid bare in these narratives, the continuous push for recognition from the survivors gathered momentum and critical and commercial success. In the years following the first collection of testimonies more literature emerged, testifying to the role of the doctors forced to collaborate with the Nazis (Lucie Adelsberger's Auschwitz: A Doctor's Story), the heroism of the underground resistance movements (Rudolf Vrba's I Escaped from Auschwitz), and the full horror of the Sonderkommando Jews - those who could have defiantly responded to Robert 
Faurisson with the claim that they did see with their own eyes the gas chambers and the crematoria destroying the Jews and the 'others' of Europe in their millions. It was in this period that Shoah (and Holocaust) literature developed as a genre with its own distinct characteristics and recurring themes.

The genre of Shoah literature gave a voice to those across Europe who were sidelined and silenced by the Nazis' campaign against the so-called 'undesirables' of the imagined Hitlerian utopia. For survivors such as Elie Wiesel, writing within the field of Shoah literature gave him a defined identity and a purpose. Wiesel's literature tends to follow a consistent trajectory regardless of the text, narrative or style. Wiesel, via his literary characters, represents the agony of the religious Jews, pushed to the brink by the trauma and the memories of the Shoah, who channel their pain through their protest to and against God as their faith and ideological beliefs collapse. As Wiesel is a first-hand survivor and also a second-generation victim in the sense that he lost his parents (his mother at Birkenau and his father at Buchenwald), he assumes a certain level of authority and ownership of the Shoah and its literary representation.

Faced with the task of framing a near-incomprehensible event within a structured narrative, and with the dual complications of trauma and time presenting themselves to the survivor, most testimonies follow some typical and easily discernible conventions. Most are framed as one chronologically recalled story, beginning with the deportation from home to camp (mostly Auschwitz-Birkenau) in cramped cattle wagons. In every case the chaos and trauma of the unloading ramp and selection process is recalled, and most survivors name the infamous Dr Mengele as being present at the selection. The flames and smoke of the crematoria chimneys, accompanied by the unmistakable choking stench of burning bodies, are other familiar motifs of the Shoah story. Levi's final narrative The Drowned and the Saved, which does not follow this convention, but frames his exploration of the issues of his Holocaust memory in a series of essays, contains the following statement, which summarizes the question of Shoah representation:

but it is also true that a memory evoked too often, and expressed in the form of a story, tends to become fixed in a stereotype, in a form tested by experience, crystallised, perfected, adorned, which installs itself in the place of the raw memory and grows at its expense. (Levi, 1988: 11-12)

\section{Holocaust fiction}

The testimonies published by the first generation of survivors set the scene and provided the details of the event in an effective 'blueprint' for replication, either in reconstructing history or in remembering events which were not lived by the authors. The emergence of Holocaust fiction is evident of the imperative for those who were not there to engage with the horror of the Holocaust in a meaningful way. As Luckhurst contends, even given the impossibility of understanding, 'silence is no option ... Adorno sets art and culture criticism of the severe, and paradoxical, imperative of finding ways of representing the unrepresentable' (Luckhurst, 2008: 5). The motifs of Shoah testimony made public by the first-generation survivors provided the imagery, the vocabulary and the topography of the Shoah for writers to simulate the Shoah experience either as a work of fiction or as 
a deliberately false testimony. Binjamin Wilkomirski's Fragments and Mischa Defonseca's Surviving with the Wolves are two high-profile examples of purportedly true testimonies later exposed to be fiction, and, interestingly, both authors defended their texts with the almost identical claim that they had believed themselves to be the victims with the names and experiences of their books. As Defonseca (in reality Monique De Wael) later claimed: 'The story in the book is mine. It is not the actual reality - it was my reality, my way of surviving' (Waterfield, 2008). Levi died in 1987, before the most recent wave of authentic and discredited testimonies and before the non-testimonial Shoah literature, Fugitive Pieces included. Yet even as he wrote his final memoir of the Shoah experience in 1986, he was aware of the blurring of fact and fiction as the historiography of the Shoah, replicated and simulated time and again in the burgeoning genre of film and literature, provided a rich source of imagery accessible to anyone who chose to use it.

The greater part of witnesses, for the defence and the prosecution, have by now disappeared, and those who remain, and who (overcoming their remorse or, respectively, their wounds) still agree to testify, have ever more blurred and stylised memories; often, unbeknown to them, influenced by information they gained later from readings or the stories of others. (Levi, 1988: 8)

In terms of the hierarchy of voices with regard to the Holocaust, the author of Holocaust fiction is neither a survivor nor reporting on behalf of one. For such authors there exists a simultaneous demand to interact with the Holocaust in a meaningful way combined with a need to respect those genuine voices which arose from the ruins of the camps. Such texts are, in Genette's taxonomy of hypertexts, serious pastiche or a forgery (albeit in some cases a forgery which identifies itself as such) in that they mimic testimony.

\section{Fugitive Pieces and historical fiction}

Fugitive Pieces is a novel about memory, history, time and place. Written by first-time novelist Anne Michaels, who was previously known for her musical compositions and poetry, Fugitive Pieces is the story of Jakob Beer. The text begins with Jakob as a sevenyear-old Jewish boy. The Nazis have broken into his Polish home, murdering his parents and sister Bella. The fugitive Jakob emerges from the mud of his town and is discovered by Greek geologist Athos Roussos, who adopts the boy, taking him back to live with him on a Greek island and later to Canada. Through his bond with Athos, the pieces of Jakob's shattered life are put together again and recorded through his poetry, which provides the historical narrative for the second half of the novel, Ben's story. Ben, the Canadian son of Holocaust survivors, also leaves a 'drowned city' and travels to Greece to trace the life and works of the late Jakob. Immersed in Jakob's words, Ben experiences the same worlds of Shoah trauma, silenced women and the power of the place that fragmented Jakob's life, replicated in the second-generation survivor.

Michaels' Fugitive Pieces makes no claim to be a truthful representation of the author's life and experience. It does, however, follow many of the conventions of the Shoah genre despite it not being a Shoah testimony in the style of most others. Michaels seems at times to be constructing a 'typical' survivor's tale through reference to other 
genuine testimony. Michaels' literature shares with the work of Wilkomirski and Defonseca the use of the Jewish orphaned child victim of the Shoah as a channel for the narrative. This motif can most obviously be traced back to Elie Wiesel's trajectory (even though Wiesel did not lose his father until the end of his experience and survived in the camps ostensibly as an adult despite being only 15).

The repeated assertion of Jewish identity in second-generation and imagined testimony is a defiant response of its own. The Jews were the Other to be silenced, their history and collective voice to be totally eliminated from Europe. In writing through a Jewish voice, the author of the real or performed Shoah experience situates their story in direct response to the Final Solution and its primary intent. The child victim offers a heightened emotional edge to the role of witness, emphasizing the vulnerability and trauma the victim suffers. In the young child Jakob's epic journey, from sinking into the mud of the city of Biskupin to hide from the Nazis to his rescue and life on a Greek isle, the fantastic escape from the evil Nazis who rob Jakob of everything he has, leaving him only with the ghost of his beloved sister Bella, reads like a serious pastiche of the Holocaust story. In the identification of the fictive nature of the book alongside the author's reliance upon the common tropes of Shoah literature, Fugitive Pieces occupies a complex space in that literature, in one sense embracing the motifs and the imagery of the genre and in another self-consciously distancing itself from the controversial issue of fiction masquerading as fact, the mimesis of trauma. Susan Gubar suggests that in writing about a Shoah experience through a male victim and about the male experience of trauma in the first and second generation, Michaels as a female author 'underscores her attempt to imagine suffering' without personally appropriating or performing a trauma that is not hers (Gubar, 2002: 253).

The primary female victim, Bella, is of course silenced twice over from the beginning of the text. It is Bella's silence, her innate refusal to betray her brother's hiding place, which allows Jakob to escape as Bella herself vanishes, bodily at least, from Jakob's life, her presence reduced to a ghostly haunting of her younger brother. 'I couldn't keep out the sounds: the door breaking open, the spit of buttons. My mother, my father. But worse than those sounds was that I couldn't remember hearing Bella at all. Filled with her silence, I had no choice but to imagine her face' (Michaels, 2007 [1997]: 10). Jakob's mother is also killed before the story begins. Alex becomes divorced from Jakob's life, and Ben's mother is silenced in the text by her inability to communicate with her son. In almost every respect, Michaels silences the women of her narrative and the memory of the Holocaust is performed through the male characters, emphasizing, as Gubar observes, the author's distance from the subject matter.

\section{Fugitive Pieces and beauty}

Further to Michaels' reference to existing genuine survivor tales is the adoption of a poeticized voice. Grimwood contends of the text that 'the fact that it was written by a poet is clear in its highly poeticized style' (Grimwood, 2003: 111). On occasion the eloquence of the speech encounters the genuine danger of obscuring the horror of the events described. When returning to the moment of his parent's death (Michaels, 2007: 10) and experiential, traumatic truth, Michaels writes, 'I longed to cleanse my mouth of memory' 
(Michaels, 2007: 22). This deliberate selection violation for poetic effect addresses the unspeakable silence of trauma and yet does so with such delicate alliteration and poise that the voice of the poet seems inappropriate for the subject matter. ${ }^{2}$ Athos's questioning of his friend Kostas' letters might be turned back upon Michaels: how can she 'write such awful news with such a beautiful hand?' (Michaels, 2007: 103). Jakob speaks of writing in such a way 'so that loss would wreck the language, become the language' (Michaels, 2007: 111), and yet at no point does the eloquent prose give way to such wrecked or faltering language.

Silence and the beauty of language are key elements which bind Fugitive Pieces to the wider genre of Shoah literature. The criticism Michaels experienced for using such a 'poeticized style' for a text written to a significant extent about the Shoah suggests that Fugitive Pieces has been accepted, if not fully embraced, within the field of Shoah literature. Grimwood cites Norma Rosen's comparison of Michaels with the survivor and poet Paul Celan, with the observation that the beauty of Celan's words failed to heal the memories of the experience he wrote about (Grimwood, 2003: 112). Primo Levi, who also wrote poetry and who, like Celan, committed suicide (Celan in 1970, Levi in 1987), could just as feasibly be referenced as demonstrating the failure of language to heal the wounds of the Shoah. Jean Améry, born Hans Meyer in Austria, responded to his torture at the hands of the Gestapo and to the treatment of the Jews he experienced with such revulsion that he abandoned his native German language completely and sought a new language to write under, until he too committed suicide in 1978 (Améry, 1980 [1966]: 43). All three writers were silenced by their own hand, but until their suicides the beauty and eloquence of their language became the medium through which their stories were told; the words may not have been enough to reconcile each man to his experience but they were at least an outlet for the experience of the Shoah.

Jakob's story, and latterly Ben's experience of that story, is immersed in language and words. It is significant that Jakob becomes a translator in his progression from a child traumatized by the Shoah, who can only scream 'dirty Jew' in several languages, to a wordsmith working in English and Greek (Michaels, 2007: 12-13). All the figures in the novel who are so influential on Jakob's life are wordsmiths of varying degrees. Athos is writing a book on false history and his written work is tainted with the lies of Nazi history, Jakob's history. Alex, Jakob's first wife is a 'Queen of the crossword', witty, sharp and political. Alex's use of the English language is described as 'dangerous and alive, edgy and hot' (Michaels, 2007: 132). Jakob is surrounded by language, the dangerous and alive English Alex uses with confidence, the tainted language of Nazi archaeology Athos is immersed in, the foreign words Jakob himself translates. Everyone in Michaels' text uses words except Bella, which is why she is so beautiful and powerful: her silence - the silence of one who did not survive - looms larger in Jakob's consciousness than the chaos of language in his waking life. Michaels once more silences the noise, leaving beauty. Athos dies before his book is published, Alex, passionate and intelligent, lacks Bella's ethereal beauty and is divorced from Jakob. As Falconer observes, Jakob distances himself from Alex because 'she is a wordsmith, a punster, while he is trying to work "with silences"” (Falconer, 2005: 107). Jakob remains haunted by his youth and his history because it is not exorcized by language. Bella's presence and her silence remain amidst the language which fills Fugitive Pieces. Michaels' poeticized voice remains 
throughout the novel, expressed through Jakob, but the ineffability of the Shoah remains too. Bella, the true victim of the Shoah, the one who did see 'the bottom' and did not return, does not speak through Michaels' poetic language: she remains silenced, ineffable.

To parody and to beautify the voice of a survivor is improper and yet, as Luckhurst contends, something must be said. Michaels is not a survivor of the camps: she is a poet, and as a poet she approached her subject with the language that was available to her. Michaels' solution to the simultaneous need to speak and to be silent is twofold. Primarily, she maintains a distance from the Holocaust within the text. Jakob is a survivor but he does not go to the camps. This is born out on pp. 45-6 with the refrain 'I didn't know' when describing the events of the Holocaust. Jakob occupies a position of (however slight) distance from the horrors of the Shoah. He suffers starvation, loses his family and hides from German soldiers, yet compared to many he is protected. He witnesses one atrocity, the rest are reported to him. His historical analysis is from reported events and 'photos' (Michaels, 2007: 166). Athos's protection means that he at least suffers less than others, and in this way he is positioned, like Michaels, as one who seeks to understand events he did not witness. Furthermore Michaels creates a text which continually demonstrates the author's lack of authority. Any reader can see, before even having opened the book, that the extra-diegetic author and the diegetic main character of the story share neither name nor gender. A similar example can be found in Art Spiegelman's Maus (see Spiegelman, 2003), a comic-book biography of Spiegelman's father's Auschwitz experiences. In Maus Spiegelman famously depicted the Germans as cats and the Jews as mice despite his father's testimony only referring to the characters as human. The animal metaphor (which, brilliantly, often becomes self-consciously problematic to maintain) serves as a constant reminder to any reader that Maus is the vision of one who was not there and can only imagine. Michaels chose a male protagonist for Fugitive Pieces, leaving no doubt that the extra-diegetic author and the diegetic narrative voice should not be confused. Like Ben, she positions herself as a potentially 'failed reader, an over-interpreter' (Grimwood, 2003: 123). Ben's exploration of Jakob's house mirrors Michaels' own entering into the Holocaust after the fact, and his misinterpretation of the objects he finds warns of the potential failure of archaeology and the dangers of mis-imagining history.

\section{Remembering Bella}

In this sense Fugitive Pieces is not only a work of fiction about a historical event but a discussion of the process of writing history. The locus of this discussion is Jakob's relationship with Bella. He is conscious of the fact that his memory of his sister is in part constructed through guesswork. He writes 'In my memory [Bella] plays as if she understood intimately [Beethoven's] adult passions' (Michaels, 2007: 127). Jakob remembers events from his sister's life and yet his memory requires a degree of invention. Jakob could not know Bella's emotional state when she played Beethoven, and yet for his memory to be whole and to have meaning, such a detail cannot be omitted. The reconstruction of Bella cannot be separated from Jakob's imagination. He writes 'I want to remain close to Bella. To do so, I blaspheme by imagining' (Michaels, 2007: 167). He is 
conscious, even guilty, of having invented details of his sister's past. The act of reconstruction is equated with contamination and even violation: 'Bella, my brokenness has kept you broken' (Michaels, 2007: 169). Ultimately he is unable to maintain his memory of his sister without fabrication. He accepts that 'There is a precise moment when we reject contradiction. This moment of choice is the lie we live by. What is dearest to us is often dearer than the truth' (Michaels, 2007: 166). Jakob's relationship with the memory of his sister informs the novel's approach to history as a whole. Jakob contends that 'History is amoral: events occurred. But memory is moral; what we consciously remember is what our conscience remembers' (Michaels, 2007: 138).

\section{Writing history}

In this way Fugitive Pieces indirectly addresses Hayden White's (1987) examination of historiography by examining the extent to which history can be known. In Fugitive Pieces historiography is depicted as having the same precision (or lack of it) as divination compared to science. Maurice, Jakob's friend, teaches a course with the oxymoronic title 'Ancient Weather: Predicting the Past' (Michaels, 2007: 173). White contends that history operates under the "conviction that "reality" is not only perceivable but is also coherent in its structure' (White, 1987: 122). Because historiography lacks a precise language, any attempt to communicate historical events through narrative unavoidably endows those events with meaning belonging to cultural discourses and the ideology of the historian which are not inherent in the events themselves. The act of telling, in other words, imposes meaning. White calls for the abandonment of a naive distinction between 'true' and 'untrue' histories, and alerts his readers instead to the inevitable creation of historical knowledge not through events but through the act of recording those events. The past is, in White's view, inherently inaccessible.

Michaels addresses this issue of the illusion of the transparent historical record with the refrain repeated throughout the book that 'Every moment is two moments' (2007: 138). An event does not have a single meaning but, like the multitude of testimony that followed the Holocaust, an event can be retold in a multitude of ways, through a multitude of voice and given a multitude of meanings. Jakob warns us to 'Never trust biographies. Too many events in a man's life are invisible' (Michaels, 2007: 141). Fugitive Pieces does not, however, take the malleability of the historical record to mean that historical knowledge is without value. History, rather, is the site of an ideological struggle. The Nazis were actively using the language which records history to shape the meaning of the Holocaust. As Levi famously contends :

Nazi policy was beyond racism, it was anti-matter, for Jews were not considered human. An old trick of language, used often in the course of history. Non-Aryans were never to be referred to as human, but as 'figuren', 'stücke' - 'dolls', 'wood', 'merchandise', 'rags'. (Levi, 1960: 165)

Levi's choice of title is a reaction to the systematic dehumanization of language in the camps he refers to. There is perhaps a similar self-consciousness reflected in Michaels' choice of title. Jakob is made a fugitive in the first pages of the novel and the reference 
to 'pieces', although clearly indicating the theme of archaeology which is a continuous thread of the storyline, may also be read through the Nazi vocabulary identified by Levi. Jakob, in Nazi terms, is a 'stücke', a piece. The insidious damage the Nazi ideology inflicted upon the young Jakob is evident as he is discovered by Athos in the mud of Biskupin, screaming 'the only phrase I knew in more than one language ... dirty Jew, dirty Jew, dirty Jew' (Michaels, 2007: 12-13). Jakob's vocabulary is soiled by Nazi propaganda at this early age; his process of creating his own language, his history and his identity is facilitated through Athos who transforms the fugitive boy, or piece, into the man Jakob becomes.

Jakob encounters the destructive effects on language and history as he learns English: 'with each mouthful the past was further silenced' (Michaels, 2007: 92), which refers to the same silence of which Himmler spoke in the quotation that opened this paper. The novel interrogates the question of how the characters interact with and seek to possess history, not simply in the sense of finding a 'true' history (the term is a paradox), but of giving voice to marginalized perspectives and finding a language appropriate to the communication of their own subjective history. Jakob describes the Jews fleeing Zakynthos:

In their cramped hiding places, parents tell their children what they can, a hurriedly packed suitcase of family stories, the names of relatives. Fathers give their five-year-old sons advice for married life. Mothers pass down recipes not only for haroseth on the Seder plate but for mezedhes, for cholent as well as ahladhi sto forno - baked quince, for poppyseed cake and ladhera. (Michaels, 2007: 40).

This is contrasted with the way in which the Nazis destroy history: 'They burned records and relics' (Michaels, 2007: 51). In Fugitive Pieces a war is being fought over history and the rights to create give meaning to history. Athos is working on a text called Bearing False Witness, published posthumously, which discusses the way in which 'the Nazis abused archaeology to fabricate the past ... The policy of territorial expansion Lebensraum - devoured time as well as space' (Michaels, 2007: 104). The text thus communicates an urgent need to communicate other historiographical works with alternative meanings from that chosen by Nazi historians. As a microcosm of cultural knowledge, even as he acknowledges the apparent malleability of his memory of Bella, Jakob is determined not to allow that memory to disintegrate: 'I hesitated in the doorway ... letting Bella enter ahead of me, making sure she was not left behind' (Michaels, 2007: 31).

One form which this battle over the meaning in historiographical works takes is in the recognition of Holocaust victims as individuals. In the manner of Holocaust artists in the camps, Jakob's image is recorded: 'She took me into her painting room and made a sketch of my face' (Michaels, 2007: 73). A recurring theme in the art which emerged from the camps is (as in the works of Charlotte Buresova, Aizik-Adolphe Féder, Jacques Gotko and Esther Lurie) of the detailed portrait of the prisoner, as if fighting against the Nazi attempt to dehumanize inmates and rob them of their individuality. Jakob wishes 'if each owner of each pair of shoes could be named, then they would be brought back to life' (Michaels, 2007: 50). Ben expresses a similar focus on the individual rather than the events: 'my fascination wasn't archaeology or even forensics; it was biography' (Michaels, 2007: 221). 
This need to record the individual is reflected elsewhere in Fugitive Pieces in the granular character study of Athos and others, zeroing in on their idiosyncrasies. Jakob is not interested in the events described in the diary of the Arctic explorer Taylor, but in the language used to describe those events - the 'studies with exclamation marks, as if he's continually astonished by what he's writing' (Michaels, 2007: 81).

Biography is not the only means of exploring and recording the marginalized histories identified in Fugitive Pieces, however. If historiography is a domain controlled by the Nazis, then those who seek to record histories with alternative meanings, the text suggests, must seek media other than historiography. The text explores means of communication outside traditional models of historical discourse as a vehicle for recording history. As Guelke contends, 'The discipline of history is not the only discipline concerned with the past' (Guelke, 1997: 225). These alternative forms of historical discourse are discussed below.

\section{Geography, music and history}

Human beings in Fugitive Pieces are intimately tied to their territory. Jakob asks 'What is a man ... who has no landscape? Nothing but mirrors and tides' (Michaels, 2007: 86). The earth not only contains a form of history, but informs the events and the individuals which that memory concerns. Geography in Fugitive Pieces can be understood through the lens of Jews and homeland. Bruce Chatwin contends that:

The ghettos of Eastern Europe were each a little patch of desert 'where no green thing would grow.' Jews were forbidden by their Christian masters to own land or houses; to grow their own vegetables, or practice any trade but usury. And though they were allowed to gather sticks for firewood, they might not saw a plank, in case this led to building. (Chatwin, 2005: 195)

The discussion of land and history in relation to a Jewish character inevitably encounters the concept of the Jewish homeland. As with the geopolitical battle over the meaning of events which takes place between Nazi ideology and those they sought to destroy, the concept of the Jewish homeland is one of giving meaning to history. ${ }^{3}$ Among the premises of Zionism (or rather, the many branches of Zionism) is the belief that geography and history are interlinked, or rather that a physical location contains the history of a people. The text does not simply encounter geography as a record of physical events but as containing the memory of the humans who occupied those locations. Jakob contends that an emotional relationship exists between land and the humans who live there in that 'Love makes you see a place differently' (Michaels, 2007: 82). ${ }^{4}$ Athos suggests that such a relationship is reciprocal when he advises Jakob to 'try to be buried in ground that will remember you' (Michaels, 2007: 76).

A repeated phrase in Fugitive Pieces is 'vertical time' (Michaels, 2007: 55), suggesting both archaeology and a physical dimension to time. 'History' is not simply recorded through language and images but physically in the earth. The text approaches the notion of deep time: namely, time measured in hundreds of thousands of years:

We think of weather as transient, changeable, and above all, ephemeral; but everywhere nature remembers. Trees, for example, carry the memory of rainfall. In their rings we read ancient 
weather - storms, sunlight and temperatures, the growing seasons of centuries. A forest shares a history, which each tree remembers even after it has been felled. (Michaels, 2007: 211)

The concept of deep time appears in criticism (both academic and non-academic) of $\mathrm{H}$. P. Lovecraft's works, where time is 'history on a scale against which the entirety of human history does not measure, history on a scale which the human mind cannot conceive' (Smith, 2011: 837). Time on this scale is conceptually beyond the understanding, and as such is inherently disconcerting. In Fugitive Pieces deep time is comforting in that it provides evidence that objects (as opposed to recorded 'history') exist despite human intervention. There exists a testimony outside hegemonic historiography which records itself. Such a record, it follows, will serve as evidence of the history of a land and any beings that once occupied it. A land will remember even if hegemonic historiography does not. Even this form of historical record is under threat, however: 'Himmler believed that Germany could alter even the weather of their occupied lands' (Michaels, 2007: 235). As well as geography, Fugitive Pieces renders history in the form of music, where 'After Vito sang, he played the santouri music that somehow told the story again' (Michaels, 2007: 58). As Greenstein observes, the title Fugitive Pieces 'refers not only to musical interludes from fugues to Brahms' intermezzo to Yiddish lullabies, but also to refugees from Poland to Greece to Canada' (Michaels, 2007: 5). Ben describes his father's relationship to music: 'The story of his life ... merged together with the music' (Michaels, 2007: 216). Music becomes a further means of connecting with memory outside historiography. Music also acts as a historical record in defiance of Nazi means to record history. The text describes 'Peat Bog Soldiers ... the first song ever written in a concentration camp' (Michaels, 2007: 240).

The music through which Jakob recalls Bella emphasizes the presence of the Holocaust and Jewish victimization. Bella played Beethoven's music: in fact she not only played his music, but Beethoven is described as 'her maestro' (Michaels, 2007: 23). The explicit engagement with German culture is made clear. Bella is not the wandering Jew of antiSemitic folklore: she is a cultured, beautiful and talented Germanophile. Elie Wiesel memorializes his murdered sister in a comparable way. Seven-year-old Tzipora is specifically described as having blonde hair as Wiesel (through his literary persona Eliezer) narrates the process of being removed from one ghetto to another in his hometown of Sighet, and again at the moment his mother and seven-year-old Tzipora are separated from his father and himself, and marched to the gas chambers at Birkenau (Wiesel, 2006 [1972]: 29). Tzipora could be a little German girl, an icon of the Aryan ideal; like Bella, she does not represent the Jew of Nazi propaganda, but both are destroyed by the Nazis indiscriminately. The musical motif in Fugitive Pieces in being explicitly German emphasizes the Jewish identity of the victims of the text, primarily Bella, and is a discernible trend of much Shoah literature.

\section{Conclusion}

Anne Michaels' Fugitive Pieces is a work of historical fiction in the genre of Holocaust literature. This genre is problematic in that writers (either 'survivors' or those who were not there) are compelled to engage with the events of the Holocaust whilst lacking the 
authority to do so. Michaels uses fiction as a means to examine the multitude of ways in which events can be communicated and given meaning. She does not present history in binary terms of 'truth' and 'untruth' but as a battleground over the meanings with which recorded events are imbued. The preservation of meaning in events requires not only alternative historiographical works, but alternatives to hegemonic historiography such as music and geography.

\section{Notes}

1 This text employs the terms 'Shoah' and 'Holocaust'. To distinguish between the two, the Holocaust was the mass internment and execution of gypsies, Jews, homosexuals, political prisoners and other groups during the Second World War, while the term Shoah refers only to the persecution (and specifically mass murder) of the Jews during this time period.

2 Selection violation occurs when a writer deliberately uses a word in a manner which is nonsensical. Wilfrid Hodges contends that selection violations play:

an important role in poetic or metaphorical writing. By committing a selection violation deliberately, a writer can force his prosaic readers to forget the literal sense of what he says; since they can make nothing of his words if they take them literally, they have to notice the colours and the overtones. (Hodges, 2001:21)

3 The opposing imagery - an imagery which informed Nazi beliefs - is the imagery of the Wandering Jew. The Wandering Jew is a figure from Christian legend. The character taunted Jesus on the cross and was forced to walk the earth until the Rapture. The legend inspired the anti-Semitic Nazi propaganda 'documentary' film Der ewige Jude ('The Eternal Jew') (directed by Fritz Hippler, 1940).

4 As a means of alternative discourse to historiography, the relationship of the individual, the earth and memory in Fugitive Pieces is similar to the Australian Aboriginal means of recording history through 'songlines' (see Chatwin, 2005). A songline is a stretch of land where the landmarks are connected to Aboriginal mythology. The walking of each route has an associated song. Songlines are used to measure territory, to distinguish group and family identity, to pass down mythology, to gauge the geographical and social relationship of one individual to another, and, in Aboriginal spirituality, to literally create the world. As with the description of the earth in Fugitive Pieces, geography holds the memory of the people who occupied it. The earth is thus used not simply as a means of generating historical evidence through archaeology but as a medium for recording events outside hegemonic historiography.

\section{References}

Améry J (1980 [1966]) At the Mind's Limits: Contemplations by a Survivor on Auschwitz and its Realities. Bloomington: Indiana University Press.

Chatwin B (2005) The Songlines. London: Vintage.

Falconer R (2005) Hell in Contemporary Literature. Edinburgh: Edinburgh University Press.

Gilbert M (1987) The Holocaust: The Jewish Tragedy. London: Fontana Press.

Grimwood M (2003) Postmemorial positions: reading and writing after the Holocaust in Anne Michaels' Fugitive Pieces. Canadian Jewish Studies 11: 111-30.

Gubar S (2002) Empathic identification in Anne Michaels' Fugitive Pieces: masculinity and poetry after Auschwitz. SIGNS: Journal of Women in Culture and Society 28(1): 249-76. 
Guelke L (1997) The relations between geography and history reconsidered. History and Theory 36: 191-234.

Hodges W (2001) Logic. London: Penguin.

Levi P (1960) If This Is a Man. London: Penguin.

Levi P (1988) The Drowned and the Saved. London: Abacus.

Luckhurst R (2008) The Trauma Question. London: Routledge.

Lyotard J-F (1988) The Differend: Phrases in Dispute. Minneapolis: University of Minnesota Press.

Michaels A (2007 [1997]) Fugitive Pieces. London: Bloomsbury.

Smith P (2011) Re-visioning romantic-era Gothicism: an introduction to the works and themes in the study of H. P. Lovecraft. Literature Compass 8: 830-9.

Spiegelman A (2003) The Complete Maus. London: Penguin.

Waterfield B (2008) 'Wolf woman' invents Holocaust survival tale. Daily Telegraph, 29 February. White HV (1987) The Content of the Form. Baltimore, MD: Johns Hopkins University Press.

Wiesel E (2006 [1972]) Night. London: Penguin.

Victoria Nesfield is a visiting lecturer in religious studies at Leeds Trinity University College, and York St John University, where she completed her doctorate in Holocaust Literature and Jewish identity. Her research interests cross the fields of literature and religious studies, meeting in the area of Holocaust studies, with a particular interest in the literature of Primo Levi and Elie Wiesel, literary representations of the Holocaust, diaspora identity and religious faith and identity in the camps. She has co-edited Building Communities of Reconciliation: Christian Theologies of Peace and Reconciliation (2012) and has written a paper for Building Communities of Reconciliation: Christian Responses to Situations of Conflict (2012).

Philip Smith currently resides in Beijing and, alongside his work with a local academic publishing company, is engaged in postgraduate studies with Loughborough University. His research interests include trauma studies, post-9/11 fiction, the comic book medium, American Gothic fiction, Shoah testimony, New Historicism and classical Chinese literature. His most recent work includes 'We have experienced a tragedy which words cannot properly describe: Representations of trauma in post-9/11 superhero comics', available at: http://onlinelibrary.wiley.com/doi/10.1111/j.17414113.2011.00829.x/abstract. 